Building an institution of insolvency practitioners in India

Anirudh Burman and Shubho Roy

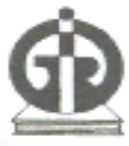

Indira Gandhi Institute of Development Research, Mumbai December 2015 http://www.igidr.ac.in/pdf/publication/WP-2015-033.pdf 


\title{
Building an institution of insolvency practitioners in India
}

\author{
Anirudh Burman and Shubho Roy \\ Indira Gandhi Institute of Development Research (IGIDR) \\ General Arun Kumar Vaidya Marg \\ Goregaon (E), Mumbai- 400065, INDIA \\ Email(corresponding author): anirudh.burman@gmail.com
}

\begin{abstract}
A good insolvency and bankruptcy regime ensures the prompt and fair resolution of financial distress. This paper identifies the rationale for creating a cadre of insolvency professionals who can play an important role in the process of rescuing, restructuring or liquidating a distressed firm. It proposes that the primary objective of creating a regulated cadre of professionals is to protect consumers i.e. the distressed firm and creditors of such firms. The primary task of regulating such professionals should be left to Self Regulatory Organisations (SROs). The state should, in turn, regulate these SROs to ensure that they are discharging their functions effectively. The paper cites evidence from other areas where SROs have played an effective regulatory role in protecting consumers. Finally, the paper ends by providing prescriptions on the regulatory framework for insolvency professionals and the SROs that would regulate them.
\end{abstract}

Keywords: Insolvency resolution, bankruptcy resolution, specialised professionals, regulation, consumer protection.

JEL Code: G33, K22, K23

\section{Acknowledgements:}

Anirudh Burman and Shubho Roy are legal consultants with the National Institute of Public Finance and Policy, New Delhi. This paper has been prepared for the Bankruptcy Law Reforms Committee constituted under the Chairmanship of Shree T.K. Viswanathan. The views expressed in this paper are personal and do not represent the views of the Committee or their employer. The authors would like to thank Susan Thomas, for her suggestions and comments on this paper, and acknowledges funding from the Finance Research Group, Indira Gandhi Institute for Development Research towards this work. The authors can be reached at anirudh.burman@gmail.com and shubho.roy85@gmail.com respectively. 


\title{
Building an institution of Insolvency Practitioners in India
}

\author{
Anirudh Burman and Shubho Roy*
}

December 24, 2015

\begin{abstract}
A good insolvency and bankruptcy regime ensures the prompt and fair resolution of financial distress. This paper identifies the rationale for creating a cadre of insolvency professionals who can play an important role in the process of rescuing, restructuring or liquidating a distressed firm. It proposes that the primary objective of creating a regulated cadre of professionals is to protect consumers i.e. the distressed firm and creditors of such firms. The primary task of regulating such professionals should be left to Self Regulatory Organisations (SROs). The state should, in turn, regulate these SROs to ensure that they are discharging their functions effectively. The paper cites evidence from other areas where SROs have played an effective regulatory role in protecting consumers. Finally, the paper ends by providing prescriptions on the regulatory framework for insolvency professionals and the SROs that would regulate them.
\end{abstract}

*Anirudh Burman and Shubho Roy are legal consultants with the National Institute of Public Finance and Policy, New Delhi. This paper has been prepared for the Bankruptcy Law Reforms Committee constituted under the Chairmanship of Shree T.K. Viswanathan. The views expressed in this paper are personal and do not represent the views of the Committee or their employer. The authors would like to thank Susan Thomas, for her suggestions and comments on this paper, and acknowledges funding from the Finance Research Group, Indira Gandhi Institute for Development Research towards this work. The authors can be reached at anirudh.burman@gmail.com and shubho.roy85@gmail.com respectively. 


\section{Contents}

1 Background 2

1.1 Why regulate insolvency practitioners? . . . . . . . . . . 3

1.2 Agents in a coercive insolvency process . . . . . . . . . . . . 4

1.3 Role of insolvency practitioner . . . . . . . . . . . . . . 4

1.4 Failures in Bankruptcy process . . . . . . . . . . . 5 5

1.5 Need for regulation of insolvency practitioners . . . . . . . . 6

2 Regulating Insolvency Practitioners $\quad 6$

2.1 Role of self-regulation . . . . . . . . . . . . . . . . 7

2.2 Modern Self-Regulatory organisations: Club to State . . . . . 10

3 Legal requirements for good insolvency practitioner SROs 12

3.1 Role of state . . . . . . . . . . . . . . . . . . 12

3.2 How to form an SRO? . . . . . . . . . . . . . . . . . 13

3.3 Entry requirements for insolvency practitioners . . . . . . . . . 14

3.4 Legal mandates/objectives for insolvency practitioners . . . . 16

3.5 Legal mandates/ objectives for SROs . . . . . . . . . . . . . 17

3.6 Accountability of SROs to Parliament . . . . . . . . . . . 18

\section{Background}

Insolvency practitioners provide specialised skills and services in an insolvency process. Their services may be utilised during an informal debt re-negotiation process, or a court supervised bankruptcy process. As such, their role is vital to the efficient operation of a country's insolvency regime. The state therefore, has an important interest in regulating the work of insolvency practitioners. The foremost reason for doing so is to protect consumers, and therefore increase the credibility of the insolvency system.

The state may regulate insolvency practitioners directly. However, such a system is limited by state capacity constraints. In addition, the state may not be in a position to understand the dynamic requirements of the profession. A solution to this is the creation of a statutory framework for licensed Self Regulatory Organisations (SROs), who in turn may regulate insolvency practitioners.

This paper analyses the need for regulating insolvency practitioners and the form which such regulation may take. In addition, it proposes a legislative framework for the functioning of insolvency practitioners, their licensing 
requirements and rights and obligations. It also proposes a framework of regulating SROs, their powers and obligations, and proposes a mechanism for holding them accountable to Parliament.

This paper begins by identifying the commercial functions of specialised insolvency professionals from the initiation of a debt re-negotiation process to end of a formal, legal bankruptcy process. It highlights the fact that insolvency practitioners perform a specialised, and vital role in the insolvency process. It also analyses the failures within the insolvency process, that if left unregulated may have systemic consequences, and therefore necessitate the threat of coercive state power.

\subsection{Why regulate insolvency practitioners?}

The process of insolvency may take place either through informal debtrenegotiation processes, or through a formal, legally mandated bankruptcy process. Professional services by insolvency professionals can involve constructing, negotiating and mediating deals, and also advising on, or implementing the restructuring and rescue of businesses. ${ }^{1}$ This fact alone however, does not necessitate the creation of a regulated profession.

The desire to protect consumers is one of the most important goals of creating a regulated profession. Consumers in a market cannot easily understand ex ante, the quality of a product particularly where specialised knowledge or skill is involved. By setting minimum standards and entry requirements, the state can ensure that consumers receive better quality services from such professionals. ${ }^{2}$ The failure to ensure quality increases the potential for low quality services. In India, chartered accountants, doctors, lawyers are examples of regulated professions. The United Kingdom ${ }^{3}$, Sweden ${ }^{4}$, are just

\footnotetext{
${ }^{1}$ Association of Business Recovery Professionals, Making a Career as an Insolvency Practitioner, URL: https : / / www.r3 . org.uk/media/documents / publications / professional/Making_a_Career_Brochure_V2.pdf (visited on 06/15/2015), See pages $2-3$.

${ }^{2}$ Maria Koumenta et al., Occupational Regulation in the EU and UK: Prevalence and Labour Market Impacts, July 2014, URL: https ://www.gov .uk/government/uploads/ system / uploads / attachment _ data / file / 343554 / bis - 14 - 999 - occupational regulation-in-the-EU-and-UK.pdf (visited on 06/16/2015).

${ }^{3}$ United Kingdom National Contact Point for professional qualifications for the UK, Regulated Professions in the UK, 2015, URL: https : / / www . naric . org . uk / UK\% 20NCP / Individuals / Regulated $\% 20$ Professions $\% 20$ in $\% 20$ the $\% 20$ UK . aspx (visited on $06 / 16 / 2015)$.

${ }^{4}$ University and UHR College Council, Regulated professions in Sweden, May 24, 2013, URL: http://www . uhr.se/Information-in-English/Qualifications-recognition/
} 
some examples of jurisdictions where many other types of professions are regulated..$^{5}$

Well designed entry barriers benefit both consumers and service providers. For regulated professionals, regulation has the effect of creating entry barriers. Minimum qualifications and professional standards enable those authorised to carry on such professions the ability to charge a better price for their services. ${ }^{6}$

\subsection{Agents in a coercive insolvency process}

A second reason for regulating insolvency practitioners is their role in a formal bankruptcy process. Debt re-negotiation is a purely commercial function. It involves a debtor and one or more creditor who negotiate to re-assess and re-formulate debt obligations. Such a negotiation may happen before, or through a formal court supervised bankruptcy process. During an informal negotiation process, the professional's role is defined strictly by the contract through which he agrees to provide services.

In a formal bankruptcy process on the other hand, the insolvency practitioner is also an agent of the state. A legal bankruptcy is the first time legal coercion is exercised upon the parties. The insolvency practitioner may be appointed an agent of the court to oversee the orderly implementation of a bankruptcy process. In certain cases, the actions or advise of the practitioner may be legally binding on both parties. State coercion should ordinarily be exercised by officers of the state. When the state grants the privilege of exercising some of its power to an external agent, it has a duty to monitor the agent, in this case, an insolvency practitioner.

\subsection{Role of insolvency practitioner}

In an informal insolvency process, the insolvency practitioner may provide a range of services discussed in Section 1.1. In a court driven bankruptcy process, the judge does the adjudication. The insolvency practitioner carries

Akademisik-start/Work-in-Sweden/Regulated-professions-in-Sweden/ (visited on $06 / 16 / 2015)$.

${ }^{5}$ See at page 22: "Overall, a total of 28 per cent of all jobs in the UK are covered by some type of regulation and this figure has been rising since 2001" Koumenta et al., see n. 2 .

${ }^{6}$ Ibid. 
out checks and accounting functions. In addition, the insolvency practitioner ensures that the due process of bankruptcy is adhered to.

In the United Kingdom, an insolvency practitioner may hold the following appointments ${ }^{7}$ :

1. Nominee or supervisor of a voluntary arrangement.

2. Interim Receiver.

3. Interim or permanent Trustee in Sequestration (Scotland only).

4. Trustee in Bankruptcy.

5. Trustee under a Deed of Arrangement.

6. Trustee of a Trust Deed for Creditors.

7. Trustee of the insolvent Estate of a deceased individual.

8. Administrator.

9. Administrative receiver.

10. Liquidator.

A well functioning system of bankruptcy driven by insolvency practitioners enables courts to delegate more and more to practitioners, thereby creating the positive externality of better utilisation of judicial time. On the other hand, the worse the performance of insolvency practitioners, the more a judge will personally supervise the process.

\subsection{Failures in Bankruptcy process}

Consumers in a well functioning market for insolvency skills are likely to have greater trust in the insolvency system. On the other hand, poor quality services, and recurring instances of malpractice and fraud erode consumer trust. In the bankruptcy process there are two main risks that regulation serves to mitigate:

\footnotetext{
${ }^{7}$ In Lorraine Conway, Regulation of Insolvency Practitioners and the handling of complaints, June 1, 2010, URL: http : / / researchbriefings . parliament . uk / ResearchBriefing/Summary/SN05531\#fullreport (visited on 06/17/2015), see page 2. The role of an insolvency practitioner is broadly similar across jurisdictions.
} 
1. Collusion: Collusion may occur between a debtor and an insolvency practitioner, between a class of creditors against another class, and against the debtor by creditors. In the first situation, the state needs to regulate to prevent the incentives for such collusion. In the second and third situations, a good insolvency practitioner may act in aid of the state by preventing collusion.

2. Poor quality execution of processes and systems: Fairness, transparency and decisiveness are key elements of a practitioner's role during the bankruptcy process. Consumers and courts will not trust a bankruptcy process that is not fair and transparent to all parties. Additionally, the process must be executed decisively in order to preserve the value of a person in bankruptcy.

\subsection{Need for regulation of insolvency practitioners}

Insolvency practitioners need to be regulated because the lack of trust in their services would lead to an erosion of trust of the insolvency process. Secondly, in a bankruptcy process, insolvency practitioners act as agents of the state. As such, regulation must ensure ${ }^{8}$ :

1. Insolvency practitioners must be competent to perform the variety of tasks they may be hired to perform in an insolvency process; and

2. Insolvency practitioners must be fair and impartial, and conflicts of interest must be minimised.

\section{Regulating Insolvency Practitioners}

State regulation of economic activity may take various forms. Certain kinds of activity are licensed and monitored directly by the state. For example, a person requires a driving license directly from the state in order to drive a vehicle. The licensing function is carried on directly by the state, and driver behaviour is also monitored by the state. In certain other cases the state cedes regulatory powers to licensed organisations who in turn license and monitor its members. Regulated professions such as lawyers, doctors and accountants are prominent examples of such a system.

\footnotetext{
${ }^{8}$ In INSOL, "Effective Insolvency Systems: Issues Note on Insolvency Representatives (Principle D8)", in: (2011), URL: https : / / www . insol . org/Africa\%20Round\% $20 \mathrm{Table} /$ Effective $\% 20$ Insolvency $\% 20$ Systems $\% 20$ discussion $\% 20$ paper .pdf (visited on 06/17/2015), see pages 3-8.
} 
There is no over-arching principle that governs the choice of this regulatory design. In practice however, the delegation of regulatory powers enables more dynamism and flexibility in the scope of regulation. State regulation is usually understood to be required to prevent and address market failures. In the financial sector for example, regulation is focused around protecting consumers, maintaining the safety and soundness of financial firms, and enforcing contracts. ${ }^{9}$ Statutory, independent regulators are established to ensure greater technical expertise and dynamism in regulation. Though such regulators are created in order to ensure more nimble regulation, all government based regulation has its limits in solving the needs of private parties. $^{10}$

\subsection{Role of self-regulation}

"...often government law enforcement is absent, too costly to use, or unknowledgeable about or uninterested in protecting property rights or contracts. Because government regulators, police, and courts are, to put it in the nicest way possible, "imperfect," private parties have potentially important unmet needs."11

As pointed out, government regulation is often inefficient and intrusive. Regulatory capture coupled with the threat of exercise of coercive power also poses risks to regulated entities and may harm consumers in the long run.

Self-regulation can solve some of these problems. It is usually assumed that self-regulatory mechanisms fail when the market is heterogeneous, or when transactions are sophisticated, or across geographical distances. However, mechanisms of private governance are far more ubiquitous and far more effective than generally accounted for. ${ }^{12}$ Additionally, government provided solutions are often too costly to use. ${ }^{13}$ Many people therefore prefer to look for less costly, private alternatives.

\footnotetext{
${ }^{9}$ Financial Sector Legislative Reforms Commission, Report of the Financial Sector Legislative Reforms Commission, Mar. 2013, URL: http://finmin.nic.in/fslrc/fslrc_ index.asp.

${ }^{10}$ Edward Peter Stringham, Private Governance: Creating Order in Economic and Social Life, Oxford University Press, 2015.

${ }^{11}$ In ibid., see page 5, and pages 13-20.

${ }^{12}$ In ibid., see pages 6-7.

${ }^{13}$ As evidence, consider the rise of private arbitration as an alternative to government provided court systems. As another example, consumers do not take telephone service providers to court every time a call drops. They live with the poor quality of service provided because contract enforcement is too expensive.
} 
Private governance mechanisms allow people with common goals to interact with each other in manageable ways. The threat of exclusion and the operation of "soft" coercive powers that operate within such clubs incentivise good behaviour. Private governance mechanisms can potentially be more dynamic, creative and diverse in the solutions they devise to solve market problems. And all of this can be done without the threat of legal coercion from the state. $^{14}$

Industry self-regulation has been explained as

“...'a regulatory process whereby an industry-level, as opposed to a governmental - or firm-level, organization (such as a trade association or a professional soci- ety) sets and enforces rules and standards relating to the conduct of firms in the industry.'...does not imply a complete substitution of industry self-control for control by the government. In fact, some form of governmental oversight and threat of direct regulation often coexist..."15

Contrary to general assumptions, self-regulation does not necessarily imply complete freedom from government regulation. Government regulation of SROs can play an important role in shaping the incentives of SROs and their members in order to produce the best possible outcome for consumers. DeMarzo, Fishman, and Hagerty (2005) demonstrate the effects of government oversight of SRO enforcement, and show that the threat of government enforcement is sufficient to induce greater enforcement by the SRO. ${ }^{16}$

A survey of self-regulated industries in the United Kingdom revealed the following advantages over statutory regulation:

"- knowledge and expertise of all parties used more effectively;

- flexible and adaptable;

- lower regulatory burden on business;

- more commitment, pride and loyalty within a profession or industry;

- lower costs to the state;

- the market can work better."17

\footnotetext{
${ }^{14}$ In Stringham, see n. 10, see page 36.

${ }^{15}$ In Anil K. Gupta and Lawrence J. Lad, "Industry Self-Regulation: An Economic, Organizational, and Political Analysis", in: The Academy of Management Review 8.3 (1983), URL: http://www.jstor.org/stable/257830 (visited on 06/15/2015), see pages 417-418.

${ }^{16}$ In Peter M. DeMarzo, Michael J. Fishman, and Kathleen M. Hagerty, "Self-Regulation and Government Oversight", in: The Review of Economic Studies 72.3 (2005), URL: http://www.jstor.org/stable/3700670 (visited on 06/10/2015), see pages 698 - 702 .

${ }^{17}$ In Ian Bartle and Peter Vass, Self-Regulation And The Regulatory State: A Survey
} 
Two common criticisms of private governance are often bandied to argue against the promotion of self-regulation. The first is that self-regulatory mechanisms end up being self-serving organisations (the Medical Council of India and the Bar Council of India are often accused of such behaviour). It must be noted however, that often, such organisations are legal monopolies.

To be effective, private governance must be viewed as a service. Consumers in a competitive market must be able to choose between different forms of private governance being provided in the market. For example, historically, stock exchanges competed for customers by providing better rules for the operation of the exchange and the behaviour of its members. The leading stock exchanges of today competed to provide better governance much before state regulation of securities markets developed. ${ }^{18} \mathrm{~A}$ competitive market of private governance is therefore necessary in order to ensure entities governing its members have to compete in order to remain in demand.

Another recurring criticism is the inability of self-regulatory organisations to enforce good behaviour against its members in order to protect consumers (again, the MCI and BCI are often touted as examples of SROs who have failed to enforce good behaviour among its members and protect consumers). There is however sufficient evidence to the contrary (Stringham (2015), and King and Lenox(2000)), highlighting how "industry self-regulation can still operate to shape and control behavior in the absence of explicit sanctions". ${ }^{19}$

Competition also increases incentives on SROs to enforce codes of conduct on its members. In any case, the legal framework enabling SROs must incentivise SROs to enforce its rules against its members, both by explicitly requiring such behaviour, and by promoting competition.

In India, major inadequacies in the fields of contract enforcement, law and order, property rights and the development of markets continue to persist in spite of extensive government intervention. Some of these problems can be, and are mitigated through private forms of governance. Historically, private forms of governance have been effective in overcoming classical problems ascribed to self-governing clubs: externalities, self-serving behaviour, and unfair exclusion. ${ }^{20}$

Of Policy And Practice, 2005, URL: http://www.bath.ac.uk/management/cri/pubpdf / Research_Reports/17_Bartle_Vass.pdf (visited on 06/18/2015), see page 2 .

${ }^{18}$ See generally Stringham, see n. 10.

${ }^{19}$ In Andrew A. King and Michael J. Lenox, "Industry Self-Regulation without Sanctions: The Chemical Industry's Responsible Care Program", in: The Academy of Management Journal 43.4 (2000), URL: http://www.jstor.org/stable/1556362 (visited on $06 / 10 / 2015)$, see page 701 .

${ }^{20}$ In Stringham, see n. 10, see pages 21-33. 
There is therefore a role for self-regulation when creating a regulated profession of insolvency practitioners. The role of the state must be to ensure that SROs licensed by it have the right incentives to protect consumers and enforce rules against its members.

\subsection{Modern Self-Regulatory organisations: Club to State}

At an early stage of development, forms of private governance take the form of clubs. Members have to possess certain skills and competence to remain within the club, and the club will try to prevent such knowledge from falling into the hands of external persons. Club members effectively act as gatekeepers to certain forms of interaction with the state (for example, filing tax returns, statements and evidence before courts, etc.). Over the years the state-citizen interface is changing rapidly. Technology (internet websites, how-to documents, SMS alerts, mobile booking and filing applications, etc.) has enabled the state to facilitate direct citizen access without the need for gate-keepers in many areas. ${ }^{21}$

SROs must adapt to this change by re-focusing on highest values services, and aligning more closely with client interests. For example, the tax practitioners and chartered accountants in India have had to adapt to the fact that many taxpayers now prefer to assess and pay their taxes online. SROs must become less "clubby", and more cruel towards defaulters.

Self-regulatory organisations that behave like clubs must recognise that they have to compete to earn the trust of consumers. Consumers have to see value in approaching them for solving their problems. In such a scenario, clubs must evolve into "mini-regulators". A club must perform the same functions that a government regulator performs with respect to its consumers. It must create rules and standards for its members. It must create and continue to evolve relevant entry barriers, and it must have mechanisms to enforce its rules and standards effectively. ${ }^{22}$

\subsubsection{Features of a regulatory SRO}

A regulator performs all three types of functions a state performs. It performs legislative functions when it drafts regulations that are binding on regulated

\footnotetext{
${ }^{21}$ Ajay Shah, Arjun Rajagopal, and Shubho Roy, From clubs to States: The future of self-regulating organisations, Dec. 19, 2013, URL: http://ajayshahblog.blogspot.in/ 2013/12/from-clubs-to-states-future-of-self .html (visited on 06/17/2015).

${ }^{22}$ Ibid.
} 
entities. It performs executive functions when it performs supervisory and enforcement functions. It performs judicial functions when it assesses whether regulated entities are in compliance with its regulations, and imposes penalties for non-compliance. ${ }^{23}$

Modern SROs also perform similar functions. They draft standards and codes of conduct that are binding on its members. The conduct examinations to ensure only competent persons gain entry into their SRO, and so that existing members remain competent and abreast of contemporary market requirements. Finally, they address the grievances of consumers and throw out members who do not comply with the SROs rules and standards.

Standard-setting: A good SRO must ensure that it has good reputational capital in order to be competitive.

1. Entry barriers: Persons who wish to become members must be required to possess minimum conditions relating to competency (tested through examinations), risk-management capacity, etc. This is different from systems where entry barriers are low. For example, in a club-type arrangement, new members are "sponsored" by existing members. This puts the SRO at risk, since its reputational capital become vulnerable to the quality of the sponsored candidate.

2. Rules of conduct: The SRO must set standards for relationships between members, members and consumers. This includes standards relating to a member's business activities, compliance with SRO membership obligations, etc.

3. Standards for sanctioning non-compliant members: SROs must set clear benchmarks for non-compliance, and a clear mechanism for awarding and enforcing penalties.

Supervision: SROs must be incentivised to establish good systems of ensuring member compliance with SRO standards. The SRO must set in place an effective system of handling complaints from consumers. Additionally, SROs must have their own internal mechanisms to ensure its members are adhering to its standards. This may be done by instituting a system of regular reporting requirements from members. Additionally, the SRO must have the capacity to conduct inspections on its members.

Adjudication: The state must encourage and incentivise SROs to independently assess and penalise its members. Ideally, persons performing such judicial functions must be independent of the SRO and not have any conflicts

\footnotetext{
${ }^{23}$ In FSLRC, see n. 9, see page 29.
} 
of interest. As stated before, the judicial function must both be conducted impartially and effectively, and seen to be so.

A good insolvency practitioner SRO must be incentivised to perform these three functions efficiently. Government regulation enabling the establishment of such SROs must ensure a clear separation of functions, and ensure the performance of these three functions is not affected by conflicts of interest. Judicial functions, for example, must not only be carried out impartially and effectively, they must also be seen to be impartial and effective processes.

\section{Legal requirements for good insolvency prac- titioner SROs}

This Section discusses the role of the state in creating an effective regime of insolvency practitioner regulation through SROs. It explains the objectives of the state for regulating SROs. It then provides a detailed proposal for the licensing, performance and punishment of insolvency practitioners and SROs. Other countries, particularly the United Kingdom have created similar legal systems that have been successful in creating a good system for the regulation of insolvency practitioners.

\subsection{Role of state}

The state must regulate insolvency practitioners and SROs with well-defined objectives. As discussed, the over-arching objective for regulating this sector is to protect consumers. Consumer protection may be achieved through the following means:

1. Competition: The general rationale for promoting competition is that it helps achieve efficiency gains. Competing firms seek to differentiate themselves from one another - through competitive pricing, better quality of products and services, and greater innovation. All of these, in turn, culminate in the overall enhancement of consumer welfare. This rationale holds true for competition among insolvency practitioner SROs as well. Greater competition among SROs will in turn lead to generally better standards and rules and better enforcement.

Parliamentary law must set out the licensing requirements for carrying out the functions of an insolvency practitioner SRO. "Competition Policy in the Financial Sector in Latin America" (2006)finds that such licensing measures 
"can cause competition problems if the entry criteria are not well defined and the process is not transparent enough as it would confer too much discretion to the sectoral regulator". ${ }^{24}$ Regulatory licensing policy has a direct impact on the number of players in the market and hence the level of competitiveness. It must be noted that both, the BCI and MCI were established as legal monopolies i.e. they are the only statutorily recognised SROs for their respective professions.

2. Create clear performance requirements: Parliamentary law must clearly state the following for both, insolvency practitioners, and SROs. The lack of clear objectives and standards in parliamentary law creates legal uncertainty. This uncertainty usually works to the detriment of consumers who lack the resources to pursue claims against negligent or fraudulent professionals. The law must therefore clearly state:

(a) The rights and obligations of consumers, practitioners and SROs;

(b) The duty of care, and the standard of care that insolvency practitioners must maintain;

(c) The principles of non-discrimination in the establishment of entry barriers to the profession;

(d) Information that the insolvency practitioner must provide to the consumer in order to enable the consumer to make a proper decision after considering all the facts (for example, disclosures pertaining to conflicts of interest);

(e) Information insolvency practitioner SROs must endeavour to provide to consumers.

3. Ensure compliance with law: The state's primary role must be to enforce parliamentary law. As regulation is proposed to be delegated to SROs, the state can perform its enforcement functions effectively by monitoring the performance of SROs licensed by it.

\subsection{How to form an SRO?}

Parliamentary law has to set out the broad framework for recognising/ licensing professional bodies as SROs for insolvency practitioners. The $U K$ Insolvency Act has two criteria for the recognition of insolvency SROs:

1. the SRO must regulate the practice of a profession, and

2. maintains and enforces rules such that its members permitted to act as insolvency professionals are:

\footnotetext{
${ }^{24}$ See page 8
} 
(a) fit and proper; and

(b) meet requirements regarding training and experience. ${ }^{25}$

The following points may be made regarding these requirements:

1. the UK Insolvency Act implies that there must be a pre-existing professional body that regulates its members in such a way that the members are competent to be insolvency practitioners;

2. the professional body need not be restricted to regulating insolvency practitioners. In the united Kingdom, SROs for chartered accountants, etc have also been declared SROs for insolvency practitioners;

3. as implied in the UK Insolvency Act, the government must satisfy itself that (a) the professional body has the appropriate rules and standards for regulating its members, and (b) the members must be "fit and proper" and possess the training and experience to be qualified as insolvency practitioners.

A similar criteria may be adopted for the licensing of insolvency practitioner SROs in India as well. Doing so will ensure that existing SROs in other sectors will have to improve their functioning if they are to be licensed as insolvency practitioner SROs.In addition, the primary law must lay down broad criteria regarding what Parliament considers "fit and proper" with regard to insolvency practitioners.

SROs must be given legal powers to ensure they are financially autonomous and not subject to regulatory capture. This must be done by ensuring that SROs have the power to collect fees from its members for supporting its operations.

\subsection{Entry requirements for insolvency practitioners}

Entry barriers may be categorised into the following ${ }^{26}$ :

1. Licensing: A licensing regime ensures that it is unlawful to perform certain activities without meeting certain criteria. Usually the state, or an agency delegated this function by the state checks whether an applicant meets licensing criteria. Occupational licensing may raise the average skill levels in the profession, leading to better quality of services for consumers. However,

\footnotetext{
${ }^{25}$ In United Kingdom, Insolvency Act 1986, 1986, URL: http://www.legislation.gov . uk/ukpga/1986/45/pdfs/ukpga_19860045_en.pdf (visited on 06/18/2015), see Section $391(2)$.

${ }^{26}$ In Koumenta et al., see n. 2, see pages 8-9.
} 
high entry licensing requirements may make the provision of such services expensive, and crowd out low-end consumers.

2. Registration: Individuals are required to file specified information with the relevant regulatory body before carrying on a certain activity.

3. Certification: It is a voluntary mechanism where practitioners may apply to be certified as competent by a relevant regulatory body after a demonstration of competence.

4. Accreditation: Practitioners may apply for a recognition of their competence by a professional body or an industry association. The criteria and process of accreditation depends entirely on the professional body. This assumes that consumers trust the professional body or industry association that performs the function of accreditation.

Regulatory barriers may be a hybrid of one of these forms as well. It is therefore proposed that the regulatory framework imposing entry barriers for insolvency practitioners be a combination of licensing and certification:

1. Only individuals must be allowed to be licensed as insolvency practitioners.

2. Anyone who wants to be an insolvency practitioner must apply for a license from a SRO licensed by the government.

3. No one must be allowed to perform the activities that an insolvency practitioner may perform without a license from a SRO.

4. Parliamentary law must state the principles based on which SROs may create licensing requirements. Such principles must ensure a test of competence of the applicant through an impartial, non-discriminatory process.

5. Parliamentary law must state that only "fit and proper" individuals will be allowed to be licensed. Law must lay down the criteria for judging a person fit and proper, and enable SROs to create additional licensing requirements if they so require.

6. On clearing the test of competence, the SRO must have an obligation to grant a license to the applicant, subject to the conditions that the applicant is fit and proper and will abide by the rules of the SRO. SROs must be incentivised to have minimal discretion in the licensing process.

The United Kingdom imposes similar requirements. Section 390 of the $U K$ Insolvency Act states that a person is not qualified to act as an insolvency practitioner unless he is a member of a recognised professional body, or has been given an authorisation by a competent authority. ${ }^{27}$

\footnotetext{
${ }^{27}$ Section 390(2) states the following: "(2) A person is not qualified to act as an insolvency
} 


\subsection{Legal mandates/objectives for insolvency practition- ers}

As discussed in Sections 1.1 and 1.3, insolvency practitioners perform important roles in both informal debt re-negotiation process as well as the formal bankruptcy process. The state has a comparatively greater interest in ensuring the quality of services provided in the bankruptcy process. Additionally, it may not be possible to set down detailed mandates regarding the role of insolvency practitioners in an informal process.

However, parliamentary law may state the duty of care to be exercised by insolvency practitioners and the standard of care that is required to be performed. Broadly, these may be categorised under the following heads ${ }^{28}$ :

1. Obligation to act independently, objectively, and with impartiality;

2. Obligation to treat the assets of the client with honesty, transparency, and in the best interests of the client;

3. Obligation to avoid, and disclose conflicts of interest to the client if they come to the knowledge of the insolvency practitioner;

4. Obligation to act diligently;

5. Obligation to maintain confidentiality of information acquired as a result of professional relationships;

6. Obligation to act in a fiduciary capacity towards the client debtor, and the creditors as a whole, if appointed in any capacity in a bankruptcy proceeding; and

7. Obligation to not commit fraud or abuse, or exert undue influence on, or on behalf of clients. ${ }^{29}$

practitioner at any time unless at that time-

(a) he is authorised so to act by virtue of membership of a professional body recognised under Section 391 below, being permitted so to act by or under the rules of that body, or

(b) he holds an authorisation granted by a competent authority under Section 393."

${ }^{28}$ See for example, Personal Insolvency Professionals Association, Code of Professional Practice for Members, tech. rep., Personal Insolvency Professionals Association, 2014, URL: http: // webcache . googleusercontent. com/search? q=cache : CcVtmvXffQ8J : https : // www . pipa . net . au / component / phocadownload / category / 8-public-documents . html ? download=25: pipa - code - of - conduct $+\& c d=1 \& h l=e n \& c t=c l n k \& g l=i n$ (visited on 06/19/2015).

${ }^{29}$ Also see Insolvency Practitioners Association, Ethics Code for Members, tech. rep., Insolvency Professionals Association, 2014, URL: http://www.insolvency-practitioners . org.uk/download/documents/1064 (visited on 06/19/2015), pages 3-6. 
SROs may further detail each of these obligations, and must also be empowered to place additional obligations on its Members.

\subsection{Legal mandates/ objectives for SROs}

SROs must be given two basic objectives:

1. Ensuring quality: SROs must be given the specific objective of ensuring that its members are competent to practise as insolvency professionals. In order to do so:

(a) An SRO may make detailed rules explaining how it expects its members to comply with the obligations stated in Section 3.4. It may also make rules and standards of conduct over and above the obligations stated in Section 3.4.

(b) An SRO must make detailed manuals explaining the standards of conduct expected from its members in specific situations.

(c) An SRO may conduct examination for licensing members. It may also conduct regular examinations for its existing members. ${ }^{30}$

2. Ensuring fidelity: SROs must perform the primary supervisory role with regard to its members:

(a) SROs must require its members to furnish certain information regularly. Such information may pertain to details of clients (unless protected by confidentiality agreements), details of bankruptcy proceedings they have been a part of, outcomes in such proceedings, etc. SROs must frame regulations to publish such information for the benefit of consumers.

(b) SROs must inspect its members regularly. Inspections must be treated as an instrument for checking compliance with primary law and SRO rules, and also for providing inputs for corrective action. SRO members must be under an obligation to co-operate with such inspections. SROs may also require certain members to be audited by independent third-parties on a periodic basis.

(c) SROs must put in place a system to accept and redress grievances of consumers against its members. The system of grievance redress must be transparent and accessible.

(d) SROs must put in place a transparent, impartial system for imposing penalties on its members. The list of penalties that may be imposed must be set down in the SROs rules, and be compliant with parliamentary law. SROs should have the flexibility to impose a graduated system

\footnotetext{
${ }^{30}$ For example, in IPA, see n. 29 , see pages $16-18$.
} 
of penalties, where minor non-compliances result in fines, and major violations may result in expulsion from the SRO, leading to the member losing his/ her license. Parliamentary law should preferably clearly state the circumstances in which a member may be expelled from the SRO.

(e) SROs must publish the list of disciplinary actions taken against its members on its website.

\subsection{Accountability of SROs to Parliament}

In giving regulatory powers to SROs, Parliament will delegate its own powers of regulation to SROs. SROs must therefore be accountable to Parliament. Parliamentary law must therefore set out the mechanisms of accountability with regard to SROs. This must contain:

1. Reporting requirements:

(a) Government departments and independent regulators like the Securities and Exchange Board of India submit annual reports of their activities, performance, sources and details of income and expenditure to Parliament every year. Similarly, SROs must be required to submit such information to the Central Government. Parliament will, in turn hold the Central Government accountable for the performance of SROs regulated by it. ${ }^{31}$

(b) SROs must be required to report specific information such as its performance on redressing grievances and related data, its record of taking disciplinary action against members and related data, and its performance with regard to the functions stated in Section 3.5.

2. Powers of inspection: The Central Government must conduct regular inspections regarding the functions of SROs to ensure their compliance with Parliamentary law.

3. Power to impose penalties: The Central Government must be given the power to impose penalties. Parliamentary law must allow any person to file a complaint against an SRO, and allow the Central Government to take suo moto enforcement action against an SRO. The enforcement action by the state must commence with a show-cause notice to the SRO and an investigation. The investigator must submit an investigation report to an independent and impartial quasi-judicial authority. The imposition of penalties must then be pursuant to an adversorial adjudicatory process.

\footnotetext{
${ }^{31}$ In FSLRC, see n. 9, see pages 31-32.
} 
4. Power to revoke licenses: While minor violations should ordinarily result in monetary fines, in extreme cases, the Central Government should have the power to revoke licenses on two grounds:

(a) The SRO commits a major violation of its statutory obligations (that is not amenable to corrective action immediately), or has repeatedly violated its statutory obligations; and

(b) The members of the SRO have repeatedly violated their legal obligations, and the Central Government finds that the SRO has not acted diligently to prevent such action, or addressed grievances of consumers resulting from such violations in an appropriate manner. 


\section{References}

Bartle, Ian and Peter Vass, Self-Regulation And The Regulatory State: A Survey Of Policy And Practice, 2005, URL: http://www.bath.ac.uk/management/cri/ pubpdf/Research_Reports/17_Bartle_Vass.pdf (visited on 06/18/2015).

Business Recovery Professionals, Association of, Making a Career as an Insolvency Practitioner, URL: https://www.r3.org.uk/media/documents/publications/ professional/Making_a_Career_Brochure_V2.pdf (visited on 06/15/2015).

Conway, Lorraine, Regulation of Insolvency Practitioners and the handling of complaints, June 1, 2010, URL: http://researchbriefings.parliament.uk/ ResearchBriefing/Summary/SN05531\#fullreport (visited on 06/17/2015).

DeMarzo, Peter M., Michael J. Fishman, and Kathleen M. Hagerty, "Self-Regulation and Government Oversight", in: The Review of Economic Studies 72.3 (2005), URL: http://www. jstor.org/stable/3700670 (visited on 06/10/2015).

Financial Sector Legislative Reforms Commission, Report of the Financial Sector Legislative Reforms Commission, Mar. 2013, URL: http://finmin.nic.in/ fslrc/fslrc_index.asp.

Gupta, Anil K. and Lawrence J. Lad, "Industry Self-Regulation: An Economic, Organizational, and Political Analysis", in: The Academy of Management Review 8.3 (1983), URL: http://www. jstor.org/stable/257830 (visited on 06/15/2015).

INSOL, "Effective Insolvency Systems: Issues Note on Insolvency Representatives (Principle D8)", in: (2011), URL: https://www. insol.org/Africa\%20Round\% $20 \mathrm{Table} /$ Effective $\% 20$ Insolvency $\% 20$ Systems $\% 20$ discussion $\% 20$ paper . pdf (visited on $06 / 17 / 2015$ ).

Insolvency Practitioners Association, Ethics Code for Members, tech. rep., Insolvency Professionals Association, 2014, URL: http://www.insolvency-practitioners. org.uk/download/documents/1064 (visited on 06/19/2015).

King, Andrew A. and Michael J. Lenox, "Industry Self-Regulation without Sanctions: The Chemical Industry's Responsible Care Program", in: The Academy of Management Journal 43.4 (2000), URL: http://www. jstor.org/stable/1556362 (visited on 06/10/2015).

Koumenta, Maria et al., Occupational Regulation in the EU and UK: Prevalence and Labour Market Impacts, July 2014, URL: https://www.gov.uk/government/ uploads / system / uploads / attachment_data / file / 343554 / bis - 14 - 999 occupational-regulation-in-the-EU-and-UK.pdf (visited on 06/16/2015). 
Personal Insolvency Professionals Association, Code of Professional Practice for Members, tech. rep., Personal Insolvency Professionals Association, 2014, URL: http: //webcache. googleusercontent. com/search?q=cache:CcVtmvXffQ8J : https : //www . pipa.net.au/component/phocadownload/category/8-publicdocuments . html ? download=25: pipa - code - of - conduct $+\& c d=1 \& h l=e n \& c t=$ clnk\&gl=in (visited on 06/19/2015).

Shah, Ajay, Arjun Rajagopal, and Shubho Roy, From clubs to States: The future of self-regulating organisations, Dec. 19, 2013, URL: http:// ajayshahblog . blogspot . in / 2013/12/from - clubs - to - states - future - of - self . html (visited on $06 / 17 / 2015$ ).

Stringham, Edward Peter, Private Governance: Creating Order in Economic and Social Life, Oxford University Press, 2015.

Troya-Martinez, M., "Competition Policy in the Financial Sector in Latin America", in: Fourth Meeting of The Latin American Competition Forum, 2006, pp. 1-43, URL: www. oecd.org/dataoecd/31/19/38820123.pdf.

UK, United Kingdom National Contact Point for professional qualifications for the, Regulated Professions in the UK, 2015, URL: https: //www. naric.org. uk/ UK $\% 20 \mathrm{NCP} /$ Individuals / Regulated $\% 20$ Professions $\% 20$ in $\% 20$ the $\% 20$ UK . aspx (visited on 06/16/2015).

United Kingdom, Insolvency Act 1986, 1986, URL: http://www.legislation.gov . uk/ukpga/1986/45/pdfs/ukpga_19860045_en.pdf (visited on 06/18/2015).

University and UHR College Council, Regulated professions in Sweden, May 24, 2013, URL: http://www. uhr.se/Information-in-English/Qualificationsrecognition/Akademisik-start/Work-in-Sweden/Regulated-professionsin-Sweden/ (visited on 06/16/2015). 